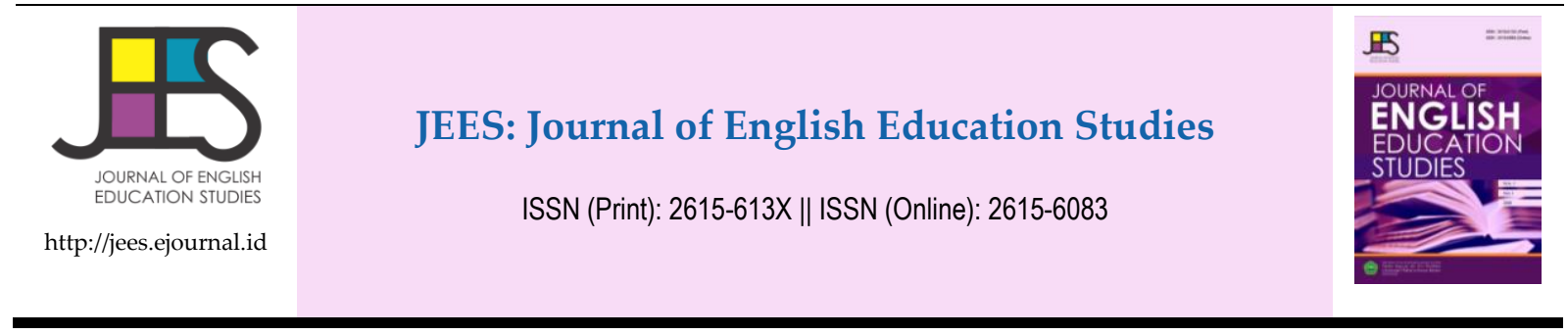

\title{
The Effect of Using Task Based Method towards Students' Listening Skill at The Seventh Grade Students of MTs Al-Ihya Kaduronyok
}

\author{
Dian Capriati ${ }^{1}$
}

${ }^{1}$ Madrasah Aliyah Al-Ihya Kaduronyok

\begin{tabular}{|c|c|}
\hline ARTICLE INFO & ABSTRACT \\
\hline $\begin{array}{l}\text { Keywords: } \\
\text { Task Based Method } \\
\text { Listening Skill }\end{array}$ & $\begin{array}{l}\text { This research paper aims to investigate the effect of using task based method in improving } \\
\text { students listening skill at the seventh grade students of MTs Al-Ihya Kaduronyok. The } \\
\text { research paper employs the quantitative research design with the characteristic of an } \\
\text { experimental study. It uses the same learning material both in experimental and control } \\
\text { class. The data are obtained from } 6 \text { sessions of classroom activity. The researcher uses } \\
\text { quantitative as the method of her research because the research designed as 'the scientific } \\
\text { method' which can be defined as a test under controlled conditions that is made to } \\
\text { demonstrate a known truth or examine the validity of a hypothesis. The findings reveal } \\
\text { that using task based method is helpful and easy to conduct. In addition, this method can } \\
\text { improve students' listening skill. In relation to the responses on the method, it is found } \\
\text { that the students respond the method positively. Based on the findings of this research, it } \\
\text { can be shown through computing t-test, the researcher got t-count (14.38) is higher than } \\
\text { t-table (1.671). It means, there is significant effect of using task based method in teaching } \\
\text { listening. }\end{array}$ \\
\hline
\end{tabular}

This is an open access article distributed under the terms of the Creative Commons Attribution 4.0 International License, which permits unrestricted use, distribution, and reproduction in any medium, provided the original work is properly cited. @ 2018 Dian Capriati.

\section{INTRODUCTION}

Language is a communication system used in the world both in spoken and written forms. It is a part of human life that exists and develops by time. In Indonesia, English has been taught start from Junior High School to university level. The material of English subject is various then teachers are obligated to choose the suitable way in order to achieve the teaching purposes easily. The materials that usually taught are based on the four basic skills of English: speaking, reading, writing and listening. The definition of listening based on Brown (2007:301) that listening is not a one-way street. It is not merely the process of an unidirectional receiving of audible symbols. One facet- the first step- of listening comprehension is the psychomotor process of receive sound waves through the

\footnotetext{
${ }^{1}$ Corresponding author's address: Madrasah Aliyah Al-Ihya Kaduronyok, Banten, Indonesia e-mail: pandadian20@gmail.com
} 
ear and transmitting nerve impulses to the brain but that is just the beginning of what is clearly an interactive process as the brain acts on the impulses, bringing to bear a number of different cognitive mechanism.Thus, Based on Richard (2008:3), there are two different perspectives of listening:

1) Listening as comprehension

Listening as comprehension is the traditional way of thinking about the nature of listening. Indeed, in most methodology manuals listening and listening comprehension are synonymous. This view of listening is based on the assumption that the main function of listening in second language learning is to facilitate understanding of spoken discourse. We will examine this view of listening in some detail before considering a complementary view of listening - listening as acquisition. This latter view of listening considers how listening can provide input that triggers the further development of second-language proficiency.

2) Listening as Acquisition

Based on the assumption that the role of listening in a language program is to help develop learners' abilities to understand things they listen to. This approach to teaching of listening is based on the following assumptions:

- Listening serves the goal of extracting meaning from messages.

- To do this, learners have to be taught how to use both bottom-up and top-down processes to understand messages.

- The language of utterances - the precise words, syntax, and expressions - used by speakers are temporary carriers of meaning.

Meanwhile, Brown (2007) states that the importance of listening in language learning can hardly be overestimated. Through reception, we internalize linguistic information without which we could not produce language. In classrooms, students always do more listening than speaking.

Listening competence is universally "larger" than speaking competence. Activities not typically employed when comprehension is the focus of listening are those that require accurate recognition and recall of words, syntax, and expressions that occurred in the input. Such activities include dictation, cloze exercises, and identifying differences between a spoken and written text. Activities such as these are often discouraged because they focus on listening for words (bottom-up listening) rather than listening for meaning (top-down listening).

Listening requires students' attention. They need to focus on the material they listen then understand it. On March 20 $0^{\text {th }}$ 2016, the researcher did an observation in MTs Al-Ihya Kaduronyok then found that some students are hard to focus on listening, cannot catch the words they listen to, do not know about the instruction to fill the task, and feel bored. Most of students assumed when they have a listening course, they only listen the speaker speaks without understanding the meaning at all. They hard to guess the words because they are lack in vocabulary and feel bored on this course because the teacher treat them by using the same method over and over.

To make the students have the strong interest in learning English especially in listening course, the teacher should take the best method. As a demanding language skill, listening has frequently been underestimated by students and educators in the field of second language acquisition because effective listening skills are developed over time with lots of practice but listening practices seem limited and the activities are most of the time decontextualized or inappropriate for students. Generally speaking, listening has attracted the least attention among the four language skills because it was regarded as a passive skill. The emergence of communicative language teaching (CLT) and the shift in language teaching from developing the linguistic competence to communicative competence was the starting point where listening skill has been considered as an active skill. 
Brown (2007: 17) says that method is a generalized set of classroom specification for accomplishing linguistic objectives. The researcher chose the task based method to solve the students' problem in listening course. The main idea behind a task-based approach to develop listening is that students become active listeners (Brown 2007). This may be completing a diagram or chart, filling in a table, or drawing a picture, for example. The task based method will help the students' listening skill because it is a method which is requiring students to process listening for functional purposes; to listen and carry out real tasks using the information.

In this case, the researcher concludes that as an essential part of communicative competence, listening is a skill that deserves equal treatment with the others, both in the classroom and in the preparation of language teaching. The English teacher needs to be well understood in applying the suitable method in teaching listening because acquiring good listening in English is a must. Teacher are supposed to improve the students' listening skills and gain valuable language input through a combination of extensive and intensive listening material and procedures. Listening of both kinds are especially important since it provides the perfect opportunity to hear other voices than the teacher's, enables students to acquire good speaking habits as a result of the spoken English they absorb and helps to improve their pronunciation. To understand the nature of listening processes, the teachers need to consider some of the characteristics of spoken discourse and the special problems they pose for listeners. Spoken discourse has very different characteristics from written discourse, and these differences can add a number of dimensions to our understanding of how we process speech. For example, spoken discourse is usually instantaneous. The listener must process it "online" and there is often no chance to listen to it again.

Generally the definition of 'task' goes to two different varieties. The first kind of task, as Nunan (2004: 4) states definition of pedagogical task is a piece of classroomwork that involves learners in comprehending, manipulating, producing or interacting in the target language while their attention is focused on mobilizing their grammatical knowledge in order to express meaning and in which the intention is to convey meaning rather than to manipulate form. The task should also have a sense of completeness, being able to stand alone as a communicative act in its own right with a beginning, a middle and an end.

A task usually requires the teacher to specify what will be regarded as successful completion of the task. The use of a variety of different kinds of tasks in language teaching is said to make language teaching more communicative "... since it provides a purpose for a classroom activity which goes beyond the practice of language for its own sake." (Richards, 2008)

In this definition, we can see that the experts take a pedagogical perspective. Tasks are defined in terms of what the learners will do in class rather than in the world outside the classroom. They also emphasize the importance of having a non-linguistic outcome. Successful listening can also be seen in terms of the strategies the listener uses when listening. Strategies can be thought of as the ways in which a learner approaches and manages a task, and listeners can be taught effective ways of approaching and managing their listening. These activities seek to involve listeners actively in the process of listening.

Ideally, based on standard competence (SK) and basic competence (KD) on curriculum, the material involved in teaching listening at seventh grade of Junior High School is about comprehend the meaning in simple oral story. The form of the story may be in formal or non-formal situation in recount, narrative, procedure, descriptive and report which is related to the daily life. Then, teacher should apply the suitable methods and strategies that can help students to comprehend the meaning of oral story they listen to.

Buck (2001:104) identifies two kinds of strategies in listening:

- Cognitive strategies: Mental activities related to comprehending and storing input in working memory or long-term memory for later retrieval. 
- Metacognitive strategies: Those conscious or unconscious mental activities that perform an executive function in the management of cognitive strategies.

From those statements, the researcher concludes that listening is an important skill which is produced from equal treatment in classroom and needed to learn by students who are interested in language course especially English.

Meanwhile, Brown (2007) states that the importance of listening in language learning can hardly be overestimated. Through reception, we internalize linguistic information without which we could not produce language.

In classrooms, students always do more listening than speaking. Listening competence is universally "larger" than speaking competence.

In educational field, the teacher who would like to conduct a learning process should know deeply about method that he will apply in his class. Based on Harmer (2007:62), method is the practical realization of an approach. The originators of a method have arrived at decisions about types of activities, roles of teachers and learners, the kinds of material which will be helpful and some model of syllabus organization. Methods include various procedures and techniques as part of their standard fare. As the researcher explained before, listening known as a difficult skill to be mastered. It means that the English teacher should be able to choose the right method that can improve the students' listening skill. There are plenty of methods that teacher may try to apply such as Task Based Method. The main idea behind a task-based approach to develop listening is that students become active listeners (Brown 2007). With this approach, students are asked to listen to what are described as "authentic" situations and to "do something" with the information. This may be completing a diagram or chart, filling in a table, or drawing a picture, for example. The information is usually transferred from spoken text to a graphic form. Because the texts are authentic (usually semi-scripted), students cope with language being spoken at normal speed and with features such as accents, hesitations, fillers, and ellipses.

According to the explanation above, researcher thought students need to use holistic inferential strategies and teacher as the learning facilitator has to prepare anything for the student's goal in learning English by using an appropriate method in his class such as task based method.

\section{METHOD}

The participants of this study were sixty students of the seventh grade of MTs Al-Ihya Kaduronyok. In this research, the researcher chose two classes by using non-probability sampling because it draws randomly from the wider population, will be useful if the researcher wishes to be able to make generalizations, because it seeks representativeness of the wider population.

Total population of the seventh grade of MTs Al-Ihya Kaduronyok is 147 students. Muijs (2004: 37) states the population is the group you want to generalise your findings to. Or other experts, Arikunto (2006:130), states the population is a set or collection of all element prossessing one or more attributes of interest. Then, population is group of people who have same quality. For detail information, the researcher explains with the table below:

Table 1. The Number of Population

\begin{tabular}{cc}
\hline Grade & $\begin{array}{c}\text { Number of } \\
\text { Students }\end{array}$ \\
\hline $7^{\text {th }} \mathrm{A}$ & 28 \\
\hline $7^{\text {th }} \mathrm{B}$ & 30 \\
\hline $7^{\text {th }} \mathrm{C}$ & 30 \\
\hline $7^{\text {th }} \mathrm{D}$ & 31 \\
\hline $7^{\text {th }} \mathrm{E}$ & $\mathbf{2 8}$ \\
\hline Total & $\mathbf{1 4 7}$ \\
\hline
\end{tabular}


This research is a quantitative research which needs test, pre-test and post-test. Pre-test is a test which is done before treatment, whereas post-test is a test which is done after treatment. The data of this research is taken by using achievement test in listening skill. In this research, the researcher chose two classes by using non-probability sampling. Hence, the researcher took 2 classes as samples of research, they are control class and experimental class.

Considering the research was aimed to investigate the effect of task based method towards students' listening skill, the hypothesis testing is a must. The hypothesis of this research is:

$\mathrm{H}_{0}$ : There is no significant effect of using Task Based Method towards students' listening skill.

$\mathrm{H}_{\mathrm{a}}$ : There is significant effect of using Task Based Method towards students' listening skill.

The result of computation is used to test hypothesis of the research. The next step is to compare $t$ observed and $t$-table value at the degree of freedom and the level of significant 0.05 . If $t$-observed is higher than $\mathrm{t}$-table value, null hypothesis (Ho) is rejected and the alternative hypothesis (Ha) is accepted. If $\mathrm{t}$ observed is lower than table value, null hypothesis $(\mathrm{Ho})$ is accepted and the alternative hypothesis (Ha) is rejected.

\section{RESULT AND DISCUSSION}

The present study investigated the effect of task based method towards students' listening skill in MTs Al-Ihya Kaduronyok. In order to determine the listening ability of the students of MTs Al-Ihya Kaduronyok, the tests were administered to the participants. To determine the listening skill, the results of the questionnaires were analyzed. Table 2 shows the descriptive statistics for the listening skill in the control and experimental groups.

Table 2. Descriptive statistics of the listening score for the control and experimental groups

\begin{tabular}{rlrr}
\hline No. & Description & $\begin{array}{c}\text { Experimental } \\
\text { class }\end{array}$ & $\begin{array}{c}\text { Control } \\
\text { class }\end{array}$ \\
\hline 1 & Mean & 78 & 67.5 \\
\hline 2 & Standard Deviation & 3.30 & 2.70 \\
\hline 3 & Sample & 30 & 30 \\
\hline & t-count & 14.38 & \\
\hline & t-table & 1.671 & \\
\hline
\end{tabular}

Based on the data analyse above, the researcher conclude that there is significant effect of using task based method towards students listening skill, the researcher found that $t$-value is 14.38 then compares with $t$-table. At degree two-tailed test of 0.05 the researcher found that $t$-table is 1.671 .

Comparing the $\mathrm{t}$-value with $\mathrm{t}$-table, it is clear that $\mathrm{t}$-value is higher than $\mathrm{t}$-table ( $\mathrm{t}$-value $>\mathrm{t}$-table $=$ $14.38>1.671$ ). If $t$-value is higher than $t$-table, null hypothesis (Ho) is rejected and alternative hypothesis (Ha) is accepted. Thus, the null hypothesis is rejected and the alternative hypothesis is supported, that is, employing task-based method has a significant effect on the students' listening skill in MTs Al-Ihya Kaduronyok.

Table 2 indicates a significant difference emerged between the control and experimental groups at the posttest. It means that teaching listening using task-based method has significantly effective to the students' listening in the experimental group. Just in order to see the task based method activity, based on Task Based Learning Pools-m (a transfer of innovation group in Europe) here are the frameworks of task based method:

\section{Pre Task}

Raise consciousness Introduction to subject and task. Thorough introduction to topic by teacher Use of pictures, posters and demonstrations 


\section{Task Cycle}

Working with and using the target language: Activities like pair work, group work Exercises like information gap activities Gradual increase in the importance of Planning, Report, Presentation.

\section{Post Task}

Selecting, identifying and classifying common words and phrases. Practice of language and phrases in classroom. Building personal dictionaries.

Let us have a brief explanation about the different phases:

- The pre-task phase introduces the class to the topic and the task, activating topic-related words and phrases

- The task cycle offers learners the chance to use whatever language they already know in order to carry out the task, and then to improve the language, under teacher guidance, while planning their reports of the task. In the task stage the students complete the task in pairs and the teacher listens to the dialogues. Then the teacher helps to correct the completed tasks in oral or written form. One of the pairs performs their dialogue in front of the class and once the task has been completed the students will hear the native speaking teachers repeat the same dialogue so they can compare it with their own.

- The last phase in the framework, language focus, allows a closer study of some of the specific features occurring in the language used during the task cycle.

The teaching techniques required for task-based method are not very different from those of ordinary language teaching. The differences lie in the ordering and weighting of activities and in the fact that there is a greater amount of student activity, and less direct, up-from teaching. It is important to be aware of some pitfalls concerning the use of task based learning. Since it encourages students to use their own languages and vocabulary, it is necessary for the teacher to help students expand these. Otherwise students will not learn new phrases or words by themselves, but only increase skills in using the language the student already possesses.

This can also be solved by having students change who they work with, so that the stronger students can work with the students who are at a lower level where the stronger student should be told to focus on using more advanced words and phrases. This does not help the stronger students though, for that they will need the aid of the teacher.

Another very important thing to remember is that even though after the task cycle is complete, the learning process is not. The evaluation part is critical for the students to become self aware of the learning they have just gone through. Put crudely there are two parts in the learning process of task based learning of equal import. The first is to do the work and go through the tasks, the second is to get the student to think about what it is he or she has just gone through. If you the teachers do not follow up in the post task, half of the task based learning process is wasted.

\section{CONCLUSION}

This study investigated the effect of task-based methods towards the students' listening skill. The results showed that the experimental group, in which task-based activities were applied, benefited significantly from the treatment.

The performance of learners in each group at the post-test was compared through the t-test formula. The comparison between the mean values of the two groups demonstrated a significant change in the improvement of listening.

Based on the research and conclusion above, the researcher proposes he following suggestions:

- Use the foreign language as much as possible.

- Use only mother tongue when necessary for explanation of exercises. 
- The pre-task is meant to help create a good atmosphere for learning without anxiety. Give words and supporting sentences for students to use.

- The pre-task must supply words, phrases, ideas to support the individual student in the main task.

- Remember that a pre-task can be anything from for example:

- audio text

- a video clip

- a brainstorm activity

- a small exercise (cloze, cross word etc.)

- photos and web pages (what do you see?)

- Anything that will promote the foreign language and set the minds of the students into a certain context and atmosphere.

- The main task must facilitate a process where each student can activate and use his/her own strategies. Teacher role in the main task: monitoring the processes of the students working with the main task.

Remember the importance of the last step, the consciousness raising activities:

- Students repeat their process and their work with the main task - must be performed in class the process will make students realize that language is diverse and that many different structures and words give meaning and can be used for communication.

- The teacher must pick up and draw attention to relevant grammatical and semantic points in this last phase of the task based method-cycle.

Therefore, it can be concluded that through using task-based listening activities, the development of learners' listening self-efficacy will be facilitated and this method is preferable to the traditional method of teaching listening which is based on merely asking and answering question.

\section{REFERENCES}

Arikunto, S. (2006). Prosedur Penelitian Suatu Pendekatan Praktik. Jakarta: Rineka Cipta.

Brown, H. D. (2007). Teaching by Principle, An Interactive Approach to Language Pedagogy Third Edition. New York: Pearson Longman.

Buck, G. (2001). Assessing Listening. United Kingdom: Cambridge University Press.

Harmer, J. (2007). How to Teach English. England: Pearson Education.

Muijs, D. (2004). Doing Quantitative Research. Great Britain: Press Ltd.

Nunan, D. (2004). Task Based Language Teaching. University of Hong Kong : Cambridge University Press.

Richards, C. J. (2008). Teaching Listening and Speaking, From Theory to Practice. United States of America: Cambridge University Press. 